\title{
MOVEMENT PATTERNS OF FRANCISCANA DOLPHINS (PONTOPORIA BLAINVILLEI) IN BAHIA ANEGADA, BUENOS AIRES, ARGENTINA
}

\author{
Pablo Bordino ${ }^{1}$
}

\begin{abstract}
From January 1993 to July 1999, systematic sightings of franciscana dolphins were conducted from four shorebased stations in Bahia Anegada, Argentina. Data were recorded using focal animal/group sampling methods. This study tested the hypothesis that dolphin movements within Bahia Anegada were random, assuming independence of sightings. The trend in dolphin swimming movement was defined as a direction scored as "coming in", "neutral", and "going out". In total 338 sightings were recorded, with a total effort of 2674 hours. The relative frequency of franciscana sightings demonstrated that movement was significantly dependent on tidal state, rejecting the hypothesis that dolphin swimming directions within the study area are random. Significant associations were also observed in the relative frequency of sightings in relation to the shore-based stations, suggesting a differential use of the bay's habitats perhaps due to location of prey, tidal current speed, depth, and topography of the coast.
\end{abstract}

Resumen - Avistajes sistematicos de delfines franciscana fueron realizados desde cuatro estaciones de observacion en Bahia Anegada, Argentina, entre Enero 1993 y Julio 1999. Los datos fueron registrados usando muestreo focal de individuos y/o grupos. El presente estudio testeo la hipotesis que el movimiento de los delfines en Bahia Anegada fueron al azar, asumiendo independencia en los avistajes. La tendencia en el movimiento de natacion de los delfines fue definida como "entrando", "neutral" y "saliendo". En total, 338 avistajes fueron registrados con un esfuerzo de 2674 horas. La frecuencia relativa de avistajes demostro que el movimiento fue significativamente dependiente del estado de marea, rechazando la hipotesis que el movimiento de los delfines en el area de estudio es al azar. Asociaciones signifiucativas tambien fueron observadas en la frecuencia relative de avistaje en relacion a las estaciones de observacion, sugiriendo un uso diferencial del habitat debido a la ubicacion de presas, velocidad de corriente de marea, profundidad y topografia de la costa.

Keywords: South Atlantic, franciscana, Pontoporia blainvillei, ecology, diurnal movements.

\section{Introduction}

The franciscana dolphin Pontoporia blainvillei is endemic to the coastal waters of the central South Atlantic. Its coastal distribution makes it vulnerable to anthropogenic activities. Currently, the franciscana is one of the most heavily impacted cetaceans in the southwestern Atlantic coast. Incidental captures in coastal gillnets seem to pose the greatest threat to the species' survival (e.g. Praderi et al., 1989; Secchi et al., in press). An annual catch of 500 dolphins was estimated from the fisheries of the Buenos Aires coastal area in Argentina (Corcuera, 1994). Little is known of franciscana population dynamics, and despite some progress, no complete population abundance estimate along its entire range is available (Bordino and Tausend, 1998; Secchi et al., 1999). The number of discreet populations is still unknown, as are the chances for its long-term survival. Most of the biological information on this species comes from studies of specimens incidentally killed in fishing nets or found on beaches. Although franciscana matures early, between 2 and 4 years, like other cetaceans it has a low reproductive potential (Brownell, 1989; Danilewicz et al., 2000). Life span is around 20 years, however only a few individuals are likely to reach this age (Pinedo and Hohn, 2000). Consequently, the species has a low potential rate of population growth (Secchi, 1999).

Studies on wild franciscana dolphins have been scarce (Bordino et al., 1999). Due to the high levels of recorded bycatch, the absence of abundance estimates throughout its entire distribution, and biological characteristics which make it more vulnerable, this species is of special concern and warrants further research. Despite some recent progress on the species' biology, ecology and conservation issues, franciscana is still listed as "Data Deficient" in the IUCN Red Data Book (IUCN, 2000).

This study presents data on the movement patterns of franciscana in Bahia Anegada and tested the hypothesis that dolphins' movements were random, assuming independence of sightings.

\section{Material and Methods}

The study area is a coastal marsh zone which includes a group of five islands and sand embankments. However, sometimes the coast drops off steeply with depths of up to 5 meters $(\mathrm{m})$ at distances of only $10 \mathrm{~m}$ from the coastline. The tidal cycle peaks about every 12 hours (hrs), with a mean annual amplitude of about $2.5 \mathrm{~m}$. This area includes Bahia San Blas, the only developed zone in the region, where at least 20 vessels operate in shark sport fishery.

Between January 1993 and July 1999, sightings of franciscana dolphins were made from four shore-based sites surrounding Bahia San Blas. Observations were obtained from Isla Gama, Banco Nordeste, and two sites from Isla Jabali (Figure 1). Each shore site was located more than $5 \mathrm{~km}$ from each other. Observations were carried out from sighting platforms approximately $2 \mathrm{~m}$ above sea level. Effort was continuous from sunrise to sunset over $10 \mathrm{hr}$ periods covering almost complete tidal cycles. Due to seasonal variation in daylight, equal effort in each tidal state was not possible. Observations were discontinued when wind speed was greater than $35 \mathrm{~km} / \mathrm{hr}$ or by rain. Two observers were placed on each platform, 
and at least one of the observers had some previous experience in sighting franciscana dolphins. Observers rotated between the different sites twice a week throughout the fieldwork.

Due to logistic problems it was not possible to achieve the same effort levels at each site. Observers completed sampling scans by naked eye and with $7 \times 50$ reticule binoculars every 10 minutes (min). Once dolphins were sighted, the number of individuals per group, presence of calves, surfacing and diving time, behavior, swimming direction, distance from shore, and time, were recorded utilizing a chronometer and electronic compass. Weather records were also kept during all observation periods. Data were recorded using focal animal/group sampling methods. The dolphins' swimming directions were defined as "coming in" or "going out" of the bay when first sighted. Dolphin swimming directions were also scored as "neutral" if dolphins were swimming obliquely to the coastline or if they were stationary. A sighted dolphin was observed for a minimum of 30 seconds (s) and a maximum of $5 \mathrm{~min}$ to determine swimming direction. The number of sightings per unit effort (SPUE) was defined as the mean number of sightings, groups or single individuals, per hour of observation. To explore the effect of tide on the dolphin's movement, sighting data were classified into one of the four 3 hrs categories of tidal state: low, rising, high and falling tides.

To maximize independence of sightings data, dolphin groups of equal size sighted in the same area during an one hour observation period were excluded from the analysis. Data were clustered by year when homogeneity was accepted, and analyzed using non-parametric tests when normality and homogeneity were rejected.

\section{Results}

In total, 338 sightings were recorded from the four shorebased stations. A total of $2674 \mathrm{hrs}$ were spent on direct observation of dolphins. Seventy-eight percent of sightings occurred during high and falling tides (Figure 2). The SPUEs recorded for each tidal state according to year are shown in Table 1. These SPUEs were not significantly different $(P=0.990$, Kruskal-Wallis test). The movement sightings and SPUEs recorded in relation to tidal cycle and shore-based station are shown in Tables 2 and 3, respectively. The mean SPUE was six times higher during high tide than low tide. The relative frequency of sightings

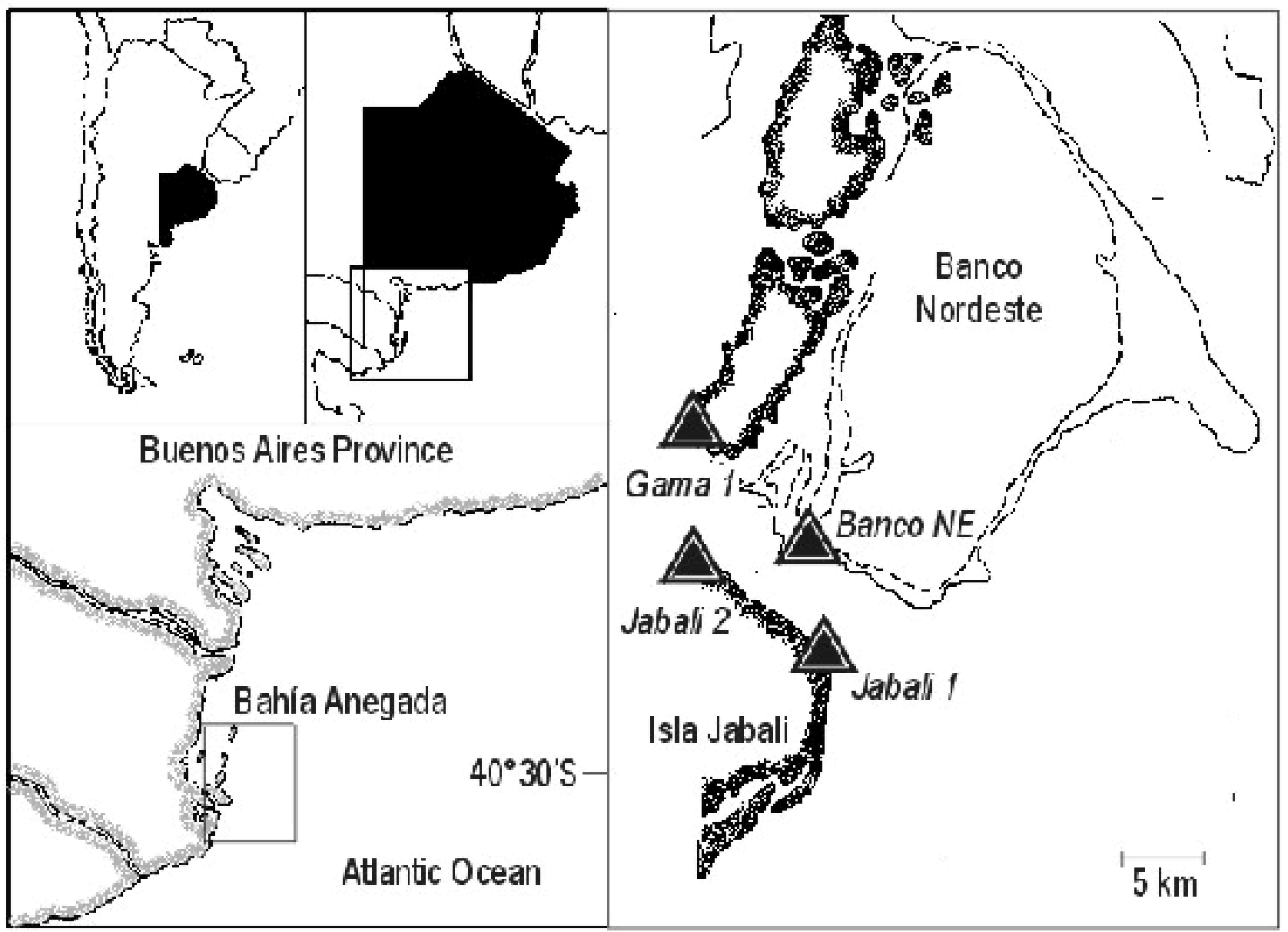

Figure 1. Locations of Bahia Anegada and shore-based positions in the study area. 
e-ISSN 2236-1057 - doi:10.5597/lajam00011

http://dx.doi.org/10.5597/lajam00011

MOVEMENT PATTERNS OF FRANCISCANA DOLLPHINS IN BAHIA ANEGADA, BUENOS AIRES, ARGENTINA

Table 1. Sightings per unit effort (SPUE) of franciscana dolphins recorded in Bahia Anegada according to tidal state and year.

\begin{tabular}{|c|ccccccc|}
\hline Tide State & $\mathbf{1 9 9 3}$ & $\mathbf{1 9 9 4}$ & $\mathbf{1 9 9 5}$ & $\mathbf{1 9 9 6}$ & $\mathbf{1 9 9 7}$ & $\mathbf{1 9 9 8}$ & $\mathbf{1 9 9 9}$ \\
\hline Low & 0.03 & 0.05 & 0.01 & 0.08 & 0.07 & 0.04 & 0.03 \\
Rising & 0.07 & 0.06 & 0.07 & 0.07 & 0.05 & 0.04 & 0.10 \\
Falling & 0.12 & 0.08 & 0.09 & 0.11 & 0.10 & 0.16 & 0.23 \\
High & 0.28 & 0.24 & 0.31 & 0.30 & 0.23 & 0.28 & 0.24 \\
\hline Total & 0.5 & 0.43 & 0.48 & 0.56 & 0.45 & 0.52 & 0.6 \\
\hline
\end{tabular}

Table 2. Total movement sightings and SPUEs of franciscana dolphins recorded in Bahia Anegada according to tidal state.

\begin{tabular}{|c|cccc|cccc|c|}
\hline Tide state & Sightings & \multicolumn{1}{|c|}{ SPUE } & & & \\
\hline & Coming in & Neutral & Going out & Total & Coming in & Neutral & Going out & Total & Effort (hs) \\
Low & 8 & 6 & 16 & 30 & 0.01 & 0.01 & 0.02 & 0.04 & 662 \\
Rising & 7 & 12 & 24 & 43 & 0.01 & 0.02 & 0.03 & 0.06 & 673 \\
Falling & 37 & 27 & 12 & 76 & 0.06 & 0.04 & 0.02 & 0.12 & 648 \\
High & 116 & 59 & 14 & 189 & 0.17 & 0.08 & 0.02 & 0.27 & 691 \\
\hline Total & 168 & 104 & 66 & 338 & 0.25 & 0.15 & 0.09 & 0.49 & 2674 \\
\hline
\end{tabular}

Table 3. Total movement sightings and SPUEs of franciscana dolphins recorded in Bahia Anegada according to shore-based station.

\begin{tabular}{|c|cccc|cccc|c|}
\hline Position & Sightings & & & SPUE & & & \\
\hline & Coming in & Neutral & Going out & Total & Coming in & Neutral & Going out & Total & Effort (hs) \\
Jabali 1 & 99 & 54 & 14 & 167 & 0.07 & 0.04 & 0.01 & 0.12 & 1399 \\
Jabali 2 & 52 & 31 & 11 & 94 & 0.07 & 0.04 & 0.02 & 0.13 & 698 \\
Gama 1 & 11 & 9 & 22 & 42 & 0.03 & 0.03 & 0.07 & 0.13 & 330 \\
Banco NE & 6 & 10 & 19 & 35 & 0.02 & 0.04 & 0.08 & 0.14 & 247 \\
\hline Total & 168 & 104 & 66 & 338 & 0.19 & 0.15 & 0.18 & 0.52 & 2674 \\
\hline
\end{tabular}

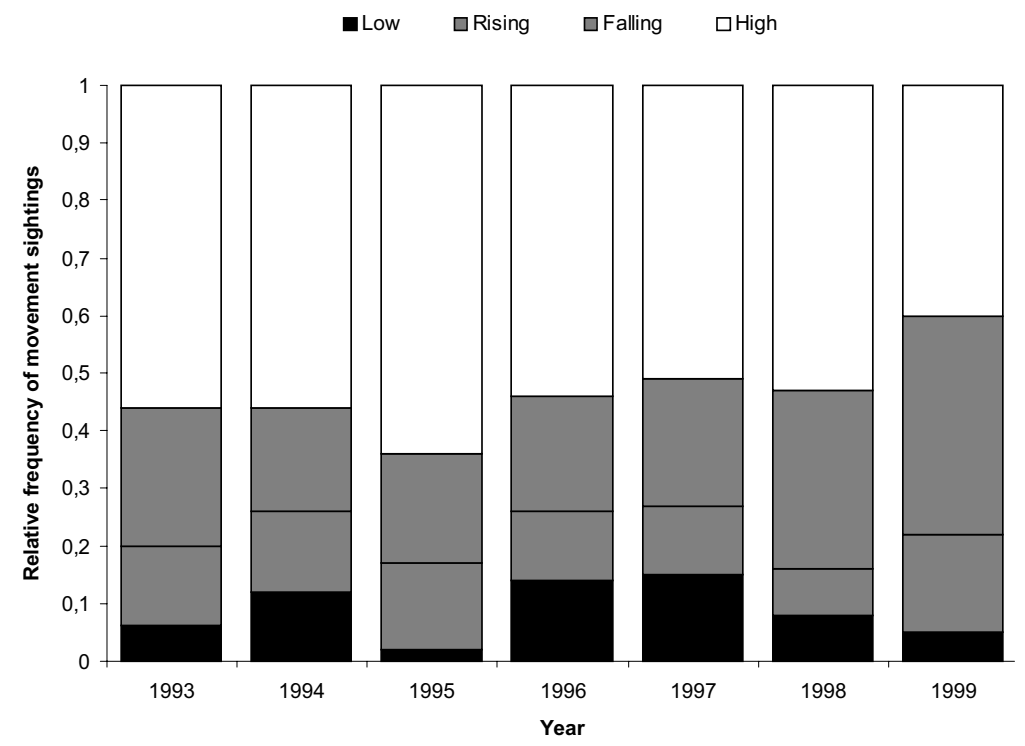

Figure 2. Relative frequency of movement sightings of franciscana dolphins according to tidal state and year. 
showed that movements of franciscana were significantly associated to tidal state $\left(P=6.4 \cdot 10^{-5}, \mathrm{RxC}\right.$ test, Figure 3$)$. Movement data provided strong evidence that dolphins were not swimming randomly inside the bay $\left(P=0.001, X^{2}\right.$ test). Significant dependencies were also observed in the relative frequency of movement sightings in relation to the shore-based stations ( $P=4.5 .10^{-6}$, RxC test, Figure 4$)$, suggesting that the majority of dolphins are coming into the bay close to Isla Jabali, and coming out close to Isla Gama and Banco Nordeste.

\section{Discussion}

In Bahia Anegada, the association between franciscana dolphins' diurnal swimming movements and tide is strong. A higher mean SPUE was recorded during high tide than low tide, and this association was consistent throughout different years. Increased sightings of dolphins when the tide is coming in may be associated with greater prey species abundance. The movements of coastal dolphin species are often associated with the

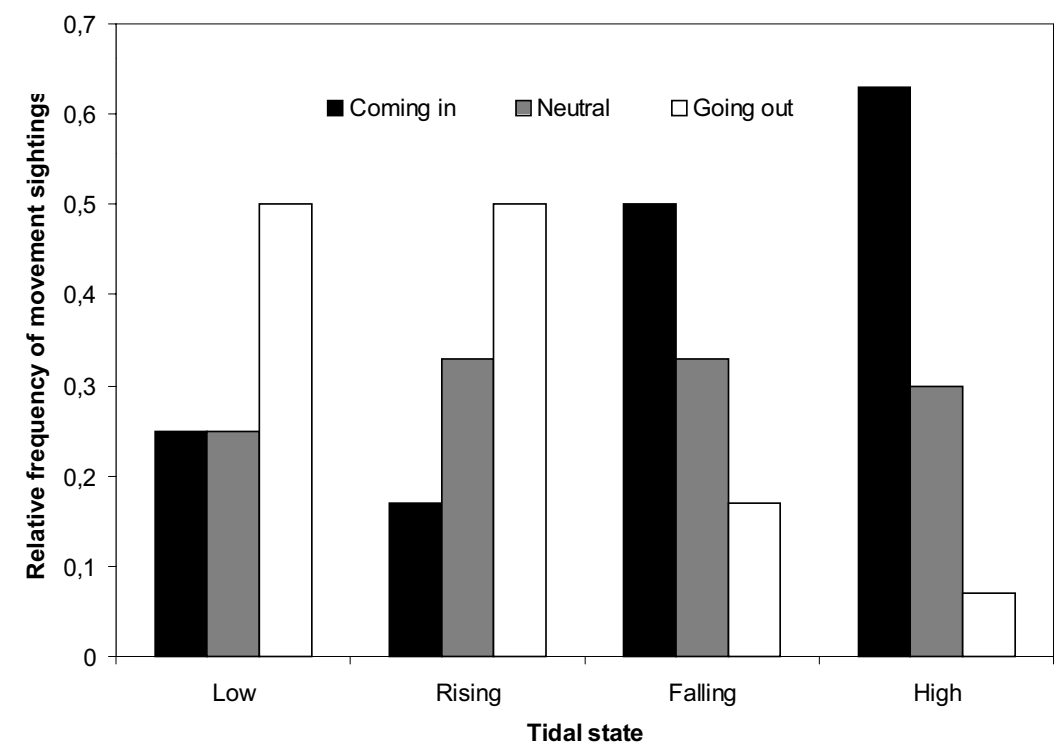

Figure 3. Relative frequency of movement sightings of franciscana dolphins in relation to tidal state.

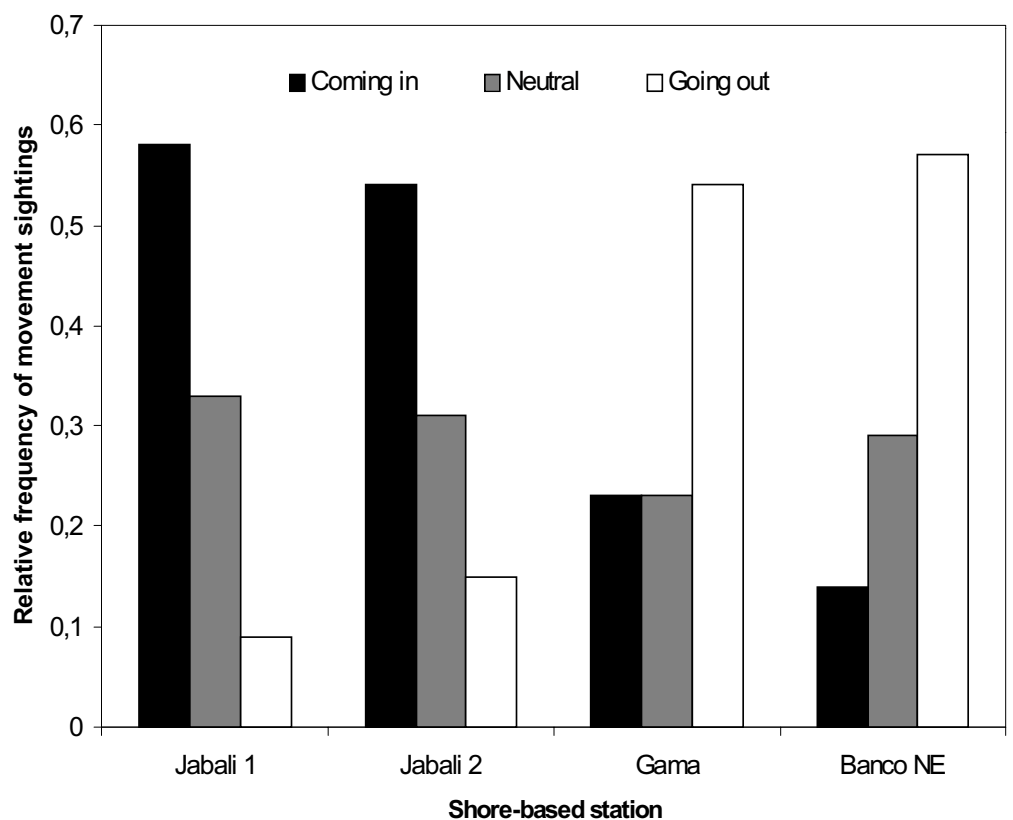

Figure 4. Relative frequency of movement sightings of franciscana dolphins in relation to shore-based stations. 
movement of prey (Gaskin, 1982). Bordino et al. (1999) demonstrated that foraging activity in franciscana dolphins was significantly higher during high tide in Bahia Anegada. The effect of the tide appears to be a decisive factor in the short-term movements of several coastal dolphin species (Caldwell and Caldwell, 1972; Wells et al., 1980; Bloom et al., 1995; Stone et al., 1995). Movement patterns in association with tidal cycles could partially explain the mechanism of entanglement in many dolphin coastal species, even in those which are not preying on fisheries targeted species as seems to be the case for franciscana dolphins. There were fewer sightings during low tide than expected, but there is no complete explanation for this difference.

Differences in the relative frequencies of movement sightings recorded from different shore-based stations may be connected to environmental factors such as current and flow patterns, current speed, depth and bottom type. These factors could have influenced the dolphins' movement inside the study area as suggested by the decrease in sightings during low tide. The average minimum swimming speed for franciscana is about $1.3 \mathrm{~m} /$ s (Bordino et al., 1999), while the tidal current in the study area is up to $1.8 \mathrm{~m} / \mathrm{s}$ (Alvarez and Rios, 1988). It would then be expected that this strong tidal current may influence the swimming speed and the movements of franciscana dolphins in Bahia Anegada. Although swimming against the current has been suggested as a feeding activity (Shane et al., 1986), swimming with a tidal current could be also used as an energy efficient strategy for foraging activities.

The influence of topography of coasts and bottoms on the movements of coastal dolphins has been previously reported (Gaskin, 1982; Evans, 1987). The coasts along Isla Jabali, Isla Gama and Banco Nordeste present topographical differences (Alvarez and Rios, 1988). Isla Jabali's coast is characterized by sand and rock beaches. This coastal area has a significantly higher mean depth than the other study areas. The coasts of both Isla Gama and Banco Nordeste are characterized by sand beaches. Differences in tidal current have been also recorded within this study area. The bottom morphology close to Isla Gama and Banco Nordeste shows evidence of strong bottom currents (Alvarez and Rios, 1988).

The relative frequency of movement sightings in relation to tide state and shore-based stations suggest that dolphins are coming in to the bay close to Isla Jabali and going out close to Isla Gama and Banco Nordeste.

As expected for most mammals, the movements of franciscana dolphins were not random inside Bahia Anegada. The movement of prey, as well as tidal current speed, depth and bottom type may produce a differential use of the habitat by this species in the study area. A long term study in Bahia Anegada may help test some of these hypotheses as well as aid in the development of effective conservation and management strategies for franciscana dolphins in Argentina.

\section{Acknowledgements}

This work could not have been possible without the help of the Prefectura Naval Argentina (Subprefectura Carmen de Patagones, Destacamento San Blas). Special thanks are given to Gustavo Thompson and all voluntary observers that helped during fieldwork. The author is indebted to Deanna Clement, Bernd Würsig and Eduardo Secchi who provided valuable comments on the manuscript. This work was supported by Wildlife Trust and the BP Conservation Programme.

\section{References}

Alvarez, J. and Rios, F. (1988) Estudios litorales en la Bahia San Blas y San Antonio Oeste. Fac. Cs. Exactas y Naturales, Universidad de Mar del Plata, Contrib. 2864, Argentina. 79pp.

Bloom, P.R.S., Goodson, A.D., Klinowska, M. and Sturtivant, C.R. (1995) The activities of a wild, solitary bottlenose dolphin Tursiops truncatus. Aquatic Mammals 21(2): 19-42.

Bordino, P. and Tausend, P. (1998) Avistabilidad y estimación preliminar de densidad del delfin franciscana Pontoporia blainvillei en Bahia Anegada, Argentina. Page 28 in Abstracts, VIII Reunião de Trabalho de Especialistas em Mamíferos Aquáticos da América do Sul, 25-29 October 1998, Olinda.

Bordino, P., Thompson, G. and Iniguez, M. (1999) Ecology and behaviour of the franciscana dolphin Pontoporia blainvillei in Bahia Anegada, Argentina. Journal of Cetacean Research and Management 1(2): 213-222.

Brownell Jr., R.L. (1989) Franciscana, Pontoporia blainvillei (Gervais and d'Orbigny 1844). Pages 45-67 in Ridgway, S.H and Harrison, R.J. (Eds) Handbook of Marine Mammals, vol 4. Academic Press, London.

Caldwell, M.C. and Caldwell, D.K. (1972) Behavior of marine mammals. Pages 419-465 in Ridgway, S.H. (Ed.) Mammals of the sea: Biology and medicine. C. C. Thomas, Springfield, IL.

Corcuera, J. (1994) Mortality of Pontoporia blainvillei in northern Buenos Aires Province: The threat of small fishing camps. Pages 291-294 in Perrin, W.F, Donovan, G.P. and Barlow, J. (Eds) Gillnets and cetaceans. International Whaling Commission (special issue) 15, Cambridge.

Evans, P.G.H. (1987) The natural history of whales and dolphins. Christopher Helm, London.

Gaskin, D.E. (1982) The ecology of whales and dolphins. Heinemann, London.

IUCN (2000) IUCN Red Data List of Threatened Species. IUCN, Gland.

Pinedo, M.C. and Hohn, A. (2000) Growth layer patterns in teeth from the franciscana, Pontoporia blainvillei: Developing a model for precision in age estimation. Marine Mammal Science 16: 1-27.

Praderi, R., Pinedo, M.C. and Crespo, E.A. (1989) Conservation and management of Pontoporia blainvillei in Uruguay, Brazil and Argentina. Pages 52-56 in Perrin, W.F., Brownell, R.L., Kaiya, Z. and Jiankang, L. (Eds) Biology and conservation of the river dolphins. Occas. pap. IUCN SSC 3. Gland.

Secchi, E.R. (1999) Taxa de crescimento potencial intrinseco de um estoque de franciscana Pontoporia blainvillei (Gervais and d'Orbigny, 1844) sob o impacto da pesca costeira de emalhe. MSc Thesis. Fundação Universidade Federal do Rio Grande, Rio Grande. 152pp.

Secchi, E.R., Ott, P.H., Crespo, E.A., Kinas, P.G., Pedraza, S.N. and Bordino, P. (2001) A first estimate of franciscana (Pontoporia 
blainvillei) abundance off southern Brazil. Journal of Cetacean Research and Management 3: 95-100.

Secchi, E.R., Ott, P.H. and Danilewicz, D.S. (in press) Effects of fishing by-catch and conservation status of the franciscana dolphin, Pontoporia blainvillei in Gales, N., Hindell, M. and Kirkwood, R. (Eds) Marine mammals and humans: towards a sustainable balance. Melbourne University Press, Melbourne.

Shane, S.H., Wells, R.S. and Würsig, B. (1986) Ecology, behavior and social organization of the bottlenose dolphin: a review. Marine Mammal Science 2(1): 34-63.

Stone, G., Brown, J. and Yoshinaga, A. (1995) Diurnal movement patterns of Hector's dolphin as observed from cliff tops. Marine Mammal Science 11(3): 395-404.

Wells, R.S., Irvine, A.B. and Scott, M.D. (1980) The social ecology of inshore odontocetes. Pages 263-317 in Herman, L. M. (Ed.) Cetacean behaviour: Mechanisms and functions. John Wiley \& Sons, New York. 